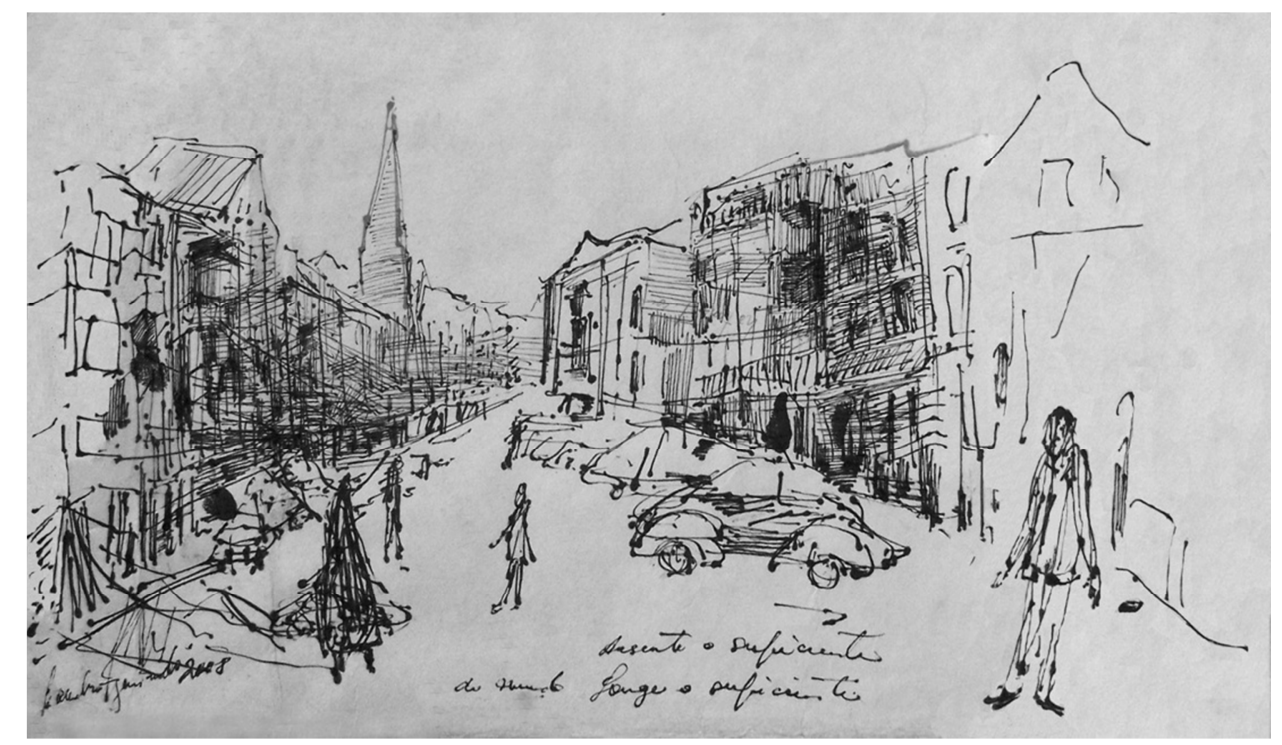

Leandro Figueiredo

\title{
CONFLUÊNCIA E IDENTIDADE
}

\section{João Jarbas Damasceno}

Bioquímico e farmacêtico. Foi vencedor, por dois anos consecutivos, do Concurso de Poesias promovido pela Universidade Federal de São João del-Rei. Participou do Concurso Raimundo Corrêa, no Rio de Janeiro, tendo seu poema publicado no livro Poetas brasileiros de hoje.

Havia um monjolo

e uma cuba de melado

e a picumã sempre

suspensa nos caibros da cozinha.

Os melros navegavam numa tarde em uníssono

em demanda dos arrozais

ou dos bambuzeiros.

Os insetos na várzea cantavam infinitos

e as cigarras no arvoredo próximo.

Tudo desafiava em conjunto.

E havia uma incosistência de haver.

Havia um mundo num estalo

e muitas luzes que espocariam

e queimariam retinas

e ar insuflado aos pulmões.

De quanta forma, quanta cor,

que matéria, tempo

há a essência do camaleão,

senão a aliada natureza; e face sua. 


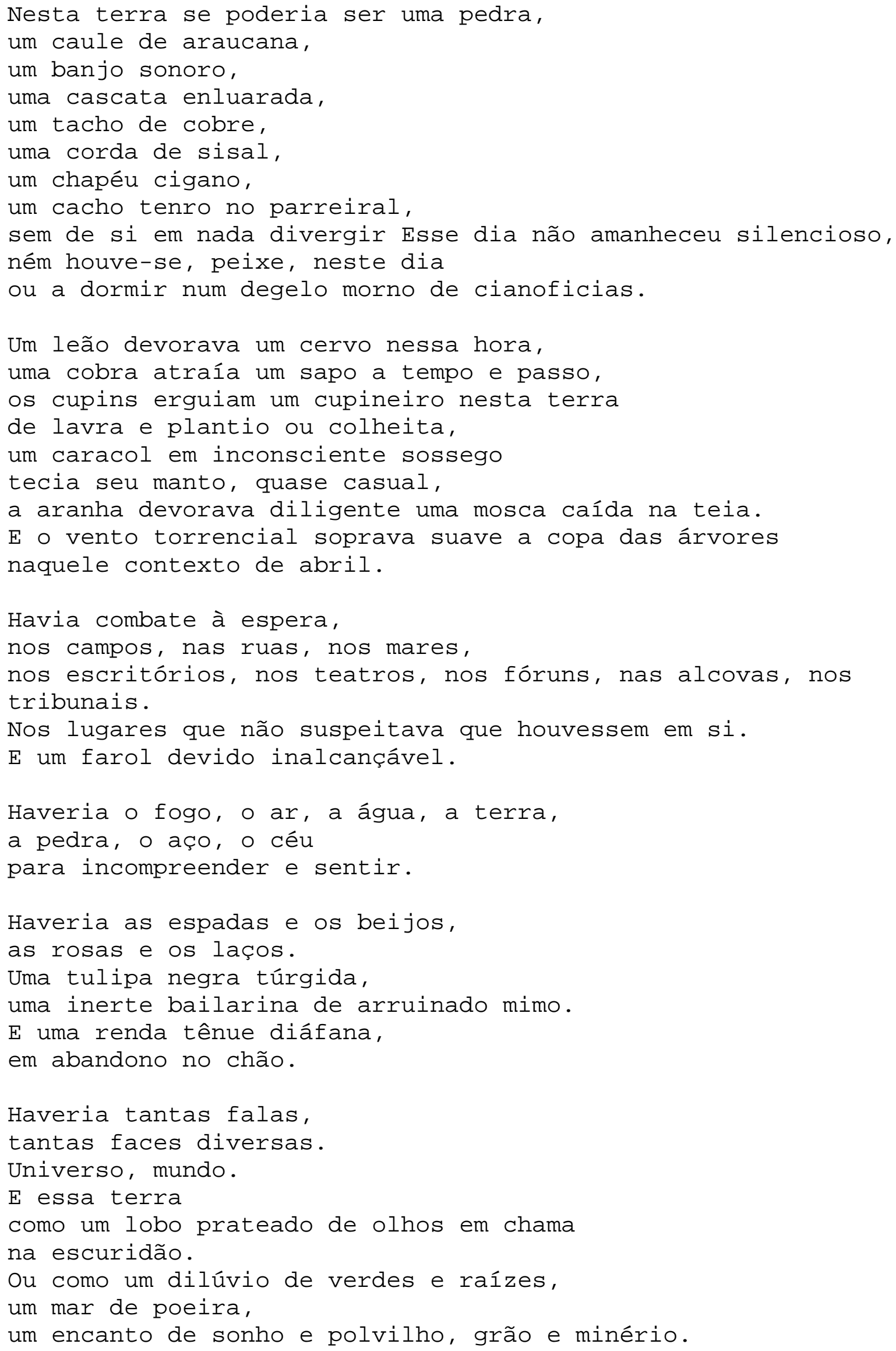


Haveria uma atmosfera voraz

de neve, lava, coriscos, avalanches

e relvas que medrariam silenciosas em entrelaçamentos.

haveria toda têmpera urdida absconsa

de todos os elementos da natureza.

Mas sobretudo esse caminho haveria

de ser insuficiente para a vida

e absoluto para a morte.

Entrementes n'algum tempo,

tudo se poderia;

a chuva, o vento, a terra própria, a nevasca e o abrasar do sol.

Foi um abril, que me viu nascer. 